\title{
Problem relating to Corporate Governance in Pakistan
}

\author{
Muhammad Aziz \\ University Of Management and Technology \\ Zahid Hafeez Gondal \\ University Of Management and Technology \\ Sajid Ali \\ University Of Management and Technology
}

\begin{abstract}
Corporate governance refers to the system in which companies controlled. Good Corporate governance stand on the principle of transparency, accountability, responsibility and fairness. It is very crucial for Pakistani companies for attaining better position in the global market in that kind of situation. This study focuses on the problems that creating hurdles corporate governance in Pakistan. In Pakistan mostly companies didn't show their full potential because of several reason mostly companies based in Pakistan are run on traditional ways and unable to meet with international standards, Due to worth of companies decreasing day by day. Mostly companies are family owned due to this they take low risk and didn't go for latest technology and on the other hand there is lack of independent directors who gave their independent view about the financial health of the company. If they heir the expertise of Ned's they gave only a fixed fee or only paying annual meeting attending fee due to this Ned's or professional engage with own work and they stay away. Pakistani companies desire to get better position an international market. But unfortunately they are very far away for attaining their desire result because they faced many problems in corporate especially governance issues. There is also top heavy system of information pass through and they take long time due to this creating problem in decision taking. And few other problems like conflict of interest, low remuneration, qualified staff, misuse of powers and lots more.
\end{abstract}

Key words: accountability, global market, non-executive independent directors (Ned's)

\section{INTRODUCTION}

Corporate governance refers to the system in which companies are governed and controlled. The directors are responsible and accountable for the governance of companies. Principles of good governance are fairness, accountability, responsibility and transparency. Good corporate governance always contributes to sustainable economic development. A sound corporate governance system always considered as a success factor of the country. It can be suggested that the policies or rules should be made that are not against the interest of all its stakeholders a Corporate derive wealth from public and also earn profit from that wealth. In doing so they consider as a socially responsible, opting into corporate social responsibility (CSR) practices (Khalid, 2016). Consequently, CSR is a concept whereby companies integrate social and environmental concerns into their business strategies, to complement financial concerns. Sustainable development means conducting business in a way not to disturb the environment of the society and protects the environmental resources in a way that will enable business to continue operating into the foreseeable future. 
As we know company had a separate legal entity and consider as a legal person. In reality it is controlled and organized by different individuals. As we know it is controlled by the boards of directors and run in the interest of its shareholders and stakeholders. It is also considered that the interest of shareholders and directors agree coincide but in practice there are so many conflict between them and these create different issues in an organization.

Different kind of ethics observed in an organization it include personal ethics that individual have in an organization professional bodies have professional ethics corporate ethics refers to how company conduct it business and employees to comply with. .

In Pakistan, the publication of the SECP Corporate Governance Code 2002 for publicly listed companies has made it an important area of research of corporate sector. The code of corporate governance introduced by SECP in early 2002 is the major step in corporate governance reforms in Pakistan. The code includes many recommendations in line with international good practice. Companies registered in Pakistan are bound to follow the rules underlying in SECP corporate governance code.

\section{LITERATURE REVIEW}

Many companies are involving and putting great effect to incorporate CSR into all aspect of their business. Many companies are already involved in CSR into their business it's necessary and beneficial for not only for a society and also for the company. The term CSR has positive impact on different stakeholders and for public (Khalid, 2016). Whenever firm performance is satisfactory, management acts independently or, some argue, is examined by the company's large and stable shareowners. When firm performance is poor, then creditors, and in particular, the firm's intervene, initiate a restructuring plan, and discipline the poorly performing management (Ameer, 2103).

Implementing all code of conducts and works under the supervision of SECP but the result is not satisfactory the SECP focus on to promote the interest the stakeholders is to ensure the business is conducting highest prevailing ethical standards (Ibrahim, 2006).

Good corporate governance are based on four major principle that are transparency, accountability, responsibility and fairness on the other hand bad corporate governance occurred when directors unable to meet its duties and fail to get sustainable development. The conflict arisen between directors and shareholders also create bad environment for the business and as a result business cannot get its full potential. Most companies locate in Pakistan are owned by closed family groups so that they want to stay away such directors that are not in their control this is a keen way to run the company for personal benefit rather than society. One of major problem is that the company doesn't pay remuneration to NED's so that the company cannot get the expertise of the expert therefore, the company cannot up-to-date the international standard and lacking his performance as compare to international companies.

Pakistani companies want to get better position in the global market but they cannot get their desire result because they faced certain issues and challenges in corporate governance like wrong belief in Pakistan that Pakistani companies are not independent and the directors of a company or other key personnel have not adequate knowledge for particular post

(Beenish, 2013).

\section{Objectives}

This study states the following objectives.

- To improve the performance of the board 
- Hire the services of expert

- To study the different key issues faced by Pakistani companies

- Improve the basic structure of companies

- Implementing the code of SECP.

- Protection of minority shareholders.

- Transparency and efficiency in corporate sector.

- Directors held responsible and accountable for what they done.

\section{Purpose of the study}

Pakistani companies wanted for attaining better position in the global market by conducting or adopting the code of conduct of corporate governance. But unfortunately they are very far away for attaining their desire result because they faced many problems in corporate especially governance issues. As we know corporate governance include all those practices, rules and process in which company is directed and controlled. The purpose of this study to identify major problems that company faced problems related to corporate governance through all available secondary resources. It is also the purpose of this study that the code will bring transparency and efficiency so that the minority shareholders get also in touch with company and their interest will protected.

\section{METHODOLOGY}

In this study looking at the objectives the research design as descriptive type. Keeping in the view of the objectives of the study and all requirements of this study the data collected with great accuracy and with depth. Data collected from all available secondary resources based on independent view looking at the current structure of the corporate sector. Different news articles, books and web are used to record data.

\section{Importance of corporate governance}

We can't neglect the importance of corporate governance at any cost. Corporate governance play a vital role not only in prosperity of a particularly in an organization but also play a vital role in the economy of a country. Corporate governance gets importance when number of cases arises in 1990's, company or board of director started to mislead the shareholder's as well as those who are directly or indirectly attached with the performance of an organization due to this the trust of all stakeholders lacking and due to this investor should not invest in any organization. These kinds of situation creating problem for other companies who are engaged their business true and with fair view. So there are various laws introduced to encourage shareholders to take part. Corporate governance is intended to increase the accountability of your company and to avoid massive disasters before they occur. Failed energy giant Enron, and its bankrupt employees and shareholders, is a prime argument for the importance of solid corporate governance. Corporate governance and economy of the country are directly or indirectly related or connected with each other. If the trust of people in the organization of a country has been developed directly it is the growth of an organization but indirectly a country can also grow.

\section{Corporate governance in Pakistan}

Corporate governance refers to the system by which companies get controlled and directed, and also proper distribution of right and responsibility among directors, shareholders, auditors, regulators and other key personnel and specifies rules through this every individual act. Governance provides structure through which corporations get their set objectives. But unfortunately Pakistani companies cannot meet their objectives and very far away from global market and other competitors due to the following reason. 


\section{Different Key Issues in Corporate Governance in Pakistan Long list of employees in organization}

Many big organization have a long list of employees who are working in an organization there are several layers of employees like president vice president and so on if the board of directors wants to get any kind of feedback from lower level of employees so the information pass through from various process and after getting back to boards of directors it passes from all heads if someone who are head of a particular department seen that the information is not sound himself better so they manipulate and change the actual information into mislead information. And the actual result was not going to leaders and therefore they cannot take right decision about the specific problem as a result the company cannot go on prosperity phase.

\section{Remuneration issues}

Mostly companies didn't want to pay remuneration on time even they have enough money to pay the remuneration. They discourage the efforts of employees they didn't give their $100 \%$ in work and as a result company suffer. Many employees involved in unethical activities.

Companies located in Pakistan also didn't pay the remuneration to Ned's they pay only a fix fee for them as a result the Ned's didn't take part in companies affairs and as a result company can't get the advantages of Ned's independence view about the company affairs. There must be a proper mechanism of remuneration so that kind of problem cannot arise.

\section{Causes of ineffectiveness of directors}

Directors are the persons who are responsible and accountable for the development of a company and they can use their expertise to take decision. But unfortunately many companies in Pakistan are family owned or by closed family groups so they didn't want any kind of interference from outside and therefore they want to stay away such directors who are not in their control due to this the directors can't take decision in their own and as a result can't able to meet with international standards.

\section{Causes of ineffectiveness of independent directors}

Independent directors give their independent view about the affairs of the company and stated the actual position of the company. But in Pakistan the independent directors are actually not independent and gave their view in the favor of the owner and as a result the company cannot get their desire result. They deceive the shareholder as well as all stakeholders who are directly and indirectly engaged with the decision of the company.

\section{Unusual post awarded to not competent people}

The most important issue arises in Pakistani companies that there are unusual post awarded to those people who are family members and close friends who haven't any know how about the particular field and they acting as a head of the particular field of the company. Due to this the company suffered and as a result they even can't stand on their feet and taking debt to survive.

\section{Boards of directors can't considered themselves as an accountable}

Boards of directors are responsible and accountable for what he had done because they have powers to run the country into their own way but in Pakistan the board of directors can't consider themselves as an accountable for what he had done. It is the responsibility of directors to work in the favor of shareholders and all stakeholders and it has been observed that even the stretch condition of the company the boards of directors enjoyed heavy bonuses and lots more incentives. 


\section{Difference between director motive and shareholders}

The shareholders motive is to maximization of wealth in long term but on the other hand Directors motive in short term in order to enjoy incentives therefore a conflict arises between them this lead to distrust among them and as result companies get suffer. There must be proper planning and mutual consideration about future prospects.

\section{Family owned companies}

Many companies in Pakistan are family owned or closed family group therefore they want those directors who run the companies affaires in their own way and they didn't want to take the services of independent directors and they stay away those directors whom they are unable to control and didn't want to take high risk therefore they can't meet the international requirements and as a result the growth of company sustained.

\section{Misuse of powers}

Many directors can take advantage of their powers and take many decisions that are not in the favor of company shareholders but beneficial for themselves. As a result the trust of shareholders lacking and they withdraw their share and companies get sustained.

\section{No right person for the right job}

No right person for the right job every individual think about himself rather than for the company because they have not adequate knowledge for the particular post or they can involve in misuse of power many employees in organization are burden for company they haven't any knowledge they are in the company because they have closed relationship with director etc.

\section{CONCLUSION}

In developing countries like Pakistan always faced a major problem in promoting corporate sector. The economy of a country is directly or indirectly relate with corporate sector. Currently many problems have been faced by the Pakistan based companies and due to this not able to compete with international standard due to this the standard has been decreased day by day. And the non-executive directors (Ned's) are very rare in Pakistan as compared to international world. Companies should take decision to heir the service of Ned's so they gave their independent view about the true picture of a financial health of a country. Directors can't take decision themselves and if they take decision themselves if the decision were not adequate they cannot considered himself liable.

\section{References:}

Ali Adnan Ibrahim, Corporate Governance in Pakistan: Analysis of Current Challenges and Recommendations for Future Reforms, 5 Wash.U. Global Stud. L. Rev. 323 (2006).

Applied Economics Research Centre. 1990. Local Government Finance and Administration in Pakistan. Karachi.

Awan, A. W., Kamal, T., Rafique, M., Khan, S., \&amp; SZABIST, I. (2012). Corporate social responsibility in Pakistan economy. Business \&amp; Economic Review, 2(1), 1-31.

Butt, S. A. (2008), “Causes of poor situation in Pakistani Listed Companies” Pakistan and Gulf Economist. Wenger, E. \& Kaserer, C. (1998), “German banks and corporate governance: a critical view”, in K J Hopt, H Kanda, M J Roe, E Wymeersch, S Prigge (eds.)

Commission on Global Governance. 1995. Our Global Neighborhood. Oxford University Press, New York.

Human Development Centre. 1999. Human Development in South Asia 1999. The Crisis of Governance. Oxford University Press, Karachi.

IBRD. 1992. Governance and Development. The World Bank, Washington, D.C.

IBRD. 1994. Governance: The World Bank's Experience. The World Bank, Washington, D.C. 
OECD, 2003, White Paper on Corporate Governance in Asia. (Paris: Organization for Economic Co-operation and Development).

Organization for Economic Cooperation and Development (OECD). 1995. Participatory Development and Good Governance. Development Cooperation Guideline Series, Paris.

Social Policy and Development Centre (SPDC). 1997. Review of the Social Action Programme. Research Report, SPDC, Karachi.

SPDC. 1998. Social Development in Pakistan. Annual Review 1998. Hamdard University Press, Karachi.

SPDC. 1999. Social Development in Economic Crisis. Social Development in Pakistan. Annual Review 1999. Oxford University Press, Karachi.5. IBRD. 1992. Governance and Development. The World Bank, Washington, D.C.

United Nations Development Programmed (UNDP). 1997. Human Development Report 1997. Oxford University Press, New York.

Zaidi, S. Akbar. 1998; Democratic Decentralization in Pakistan: A Contradiction in Terms in Problems of Good Governance in South Asian Countries: Learning from European Political Models. Naveed Ahmed Tahis [ed]; Area Study Centre for Europe, University of Karachi and the Hans Siedel Foundation, Islamabad. 